\title{
Conducting Comparative Research into Defence Capability Formation
}

\author{
Stefan Markowski ${ }^{1,2}$, Satish Chand ${ }^{2}$, Robert Wylie ${ }^{2}$ \\ ${ }^{1}$ Chair of Management, University of Information Technology and Management, Rzeszow, Poland \\ ${ }^{2}$ School of Business, UNSW Canberra, The Australian Defence Force Academy, Canberra, Australia \\ Correspondence: Stefan Markowski, Chair of Management, University of Information Technology and Management, \\ Rzeszow, Poland; School of Business, UNSW Canberra, The Australian Defence Force Academy, Canberra, Australia.
}

Received: October 2, 2017

doi:10.11114/aef.v4i6.2751

\author{
Accepted: October 30, $2017 \quad$ Available online: October 31, 2017
}

URL: https://doi.org/10.11114/aef.v4i6.2751

\begin{abstract}
The world appears to be searching for a new, multipolar model of global security. In this context, the provision of impartial data on military capability formation to be used in disarmament proposals and balance of power negotiations will be critical to effective security management in the prevailing uncertain international environment. In their recent research paper on the relationship between military expenditure (milex), government spending and economic growth in the Indo-Pacific Asia region the authors argued that milex' high level of aggregation often masked important changes in national military capabilities and proposed limited disaggregation of military expenditure data to highlight national spending on military force structure and preparedness so as to facilitate better understanding of military capability formation. In this paper the authors develop this perspective a step further by reviewing alternative approaches to the production of data on military capability formation. It is suggested that the milex data are disaggregated one level down to differentiate between investments in the future force and expenditure on the readiness and sustainment of the force in being.
\end{abstract}

Keywords: milex, defence burden, military capability, arms race

\section{Introduction}

Economists have long been interested in the drivers of demand for military expenditure (milex), arms expenditure races as well as possible influence of milex on economic growth (see Dunne \& Nan Tian, 2016; Smith, 2009; Dunne \& Smith, 2007; Dunne, Smith \& Willenbockel, 2005; McGuire, 2007, Sandler \& Hartley 2007). It is often asserted that higher levels of GDP are likely to result in higher spending on the military although the burden of defence, defined as the share of milex in GDP, may decrease over time if the rate of income growth exceeds the rate of milex growth. In their latest international survey Dunne and Nan Tian (2016) report that milex has had a negative effect on economic growth. Earlier, Dunne et al. (2005: 450) suggested that there were three broad groups of effects that could help explain why and how milex may influence output, each group associated with particular channels through which changes in milex are transmitted to produce changes in output: (a) demand-related effects, (b) supply-related effects and (c) national security-related effects. While milex may produce both demand- and supply-related effects, we are mainly interested in explanations of how a country's increased military spending may be influenced by its strategic perceptions of threats to its sovereignty and military spending by its potential adversaries and current allies.

In our recent paper (Markowski, Chand \& Wylie, 2017) we focused on Indo-Pacific Asia - a region which roughly includes countries of South and East Asia, plus the Russian Federation, Australia, New Zealand and the United States (as the global military power that is strategically involved in the region) ${ }^{1}$ - to examine the relationship between economic growth, milex, the share of military spending in GDP (the burden of defence) and government expenditure. ${ }^{2}$ The region is interesting as it has experienced high rates of economic growth since the 1980s - especially in China and parts of East Asia - that have often been accompanied by large increases in milex. It has also a long history of territorial

\footnotetext{
${ }^{1}$ We followed Medcalf (2013) in defining Indo-Pacific Asia so as to include the United States.

${ }^{2}$ Our secondary aim was to assess the quality of the new Stockholm International Peace Research Institute (SIPRI) database in this regional context and compare the SIPRI-produced milex data with regional military budgets data published by the Australian Defence Intelligence Organisation (ADIO).
} 
disputes and ethnic conflicts. In the recent context of high economic growth and growing military expenditure, some countries have experienced declining burdens of defence while others have seen their share of milex in GDP remain invariant or increase. For example, in the 1990s and 2000s, the U.S. and China have experienced compound growth rates of milex that have been roughly in line with their rates of GDP growth. For Japan and Russia the milex growth exceeded their GDP growth and the growth of milex in India and other countries (e.g., Pakistan, Indonesia, Philippines and Vietnam) lagged behind their GDP growth. We were therefore interested to ask why milex had been a normal or a superior good for some countries (as evidenced by the constant or increasing burden of defence) but inferior good for others and, generally, how did milex growth relate to GDP growth in the region.

As we observed, the growing national incomes in the region provided the military with opportunities to make acquisitions which previously were unaffordable, respond to other pent up military demands, make additional prudent investments to deter potential threats, and, in some cases, allow their military top brass to retain 'their share' of GDP simply because they are an important and powerful interest group, which feels entitled to its share in the growing national prosperity. However, on the face of it, there was no evidence of an arms spending race in Indo-Pacific Asia. ${ }^{3}$ Our main econometric finding was that the parameter estimates failed to reject the proposition that military expenditure within the region was unit elastic with respect to GDP, which suggested that the regional milex was a normal good that changed in tandem with GDP (which also leaves open the possibility of milex being a positional good). Nevertheless, we are all well aware of and continuously reminded about strategic tensions in the region. ${ }^{4}$ There is no apparent evidence to suggest that these tensions have been lessening because the constant or declining burden of defence has provided the region with a post-cold war 'peace dividend'. This is particularly the case in an era where the hegemony of the USA through the 'command of the commons' is fading with a policy of selective engagement of the United States of America (Posen, 2003). ${ }^{5}$

Our econometric specification used to estimate the income elasticity of milex took the general form of a consumption-income relationship (Blinder, Deaton, Hall \& Hubbard, 1985) with milex representing a public or a national club good provided in a strategic context of interrelated national military spending where the USA acted as the global and regional Stackelberg leader in new capability formation (Bruce, 1990). ${ }^{6}$ We took this approach because the aggregate milex data reflect the use/consumption of national resources for military purposes but tell us nothing about what it has specifically been spent on or why it has been spent that way. To make judgements about strategic intentions - especially when arms races are defined as "enduring rivalries between pairs of hostile powers, which prompt competitive acquisition of military capability" (Dunne \& Smith, 2007: 915) - and about related military capabilities, we need a more detailed breakdown of military expenditure. Our analysis suggested positive partial correlations between military outlays of major players in the region; an observation that implies strategic behaviour but one that is statistically difficult to pinpoint from the aggregate milex data. It was apparent that there had been convergence in terms of the proportion of income used for military expenditure within Indo-Pacific Asia and that military expenditures across nations within the region were interdependent as countries formed strategic sub-systems/clusters of allies, friends and foes (see an earlier study of Markowski \& Tani, 2005). But, these findings "shed little light on the nuance and richness of the causal relationships among defence expenditure, defence budgets and GDP growth in the Indo-Pacific Asia region" (Markowski et al., 2017: 12) as aggregate measures of milex reveal little about military capability and strategic intent. Thus, we could not infer from the milex data why the regional military expenditure was roughly unit elastic with respect to GDP. This demonstrates the potential utility of disaggregating milex into outlays on the formation of future force and sustainment of the force-in-being and in particular in spending on military-specific technology, hardware, personnel, readiness and sustainment to get a better handle on military capabilities of different countries and their likely military intentions.

\footnotetext{
${ }^{3} \mathrm{We}$ also considered the priority accorded by countries in the region to the defence component of their respective national budgets during the 25 year period 1990-2014. This measure of military burden exhibited more diversity with some countries (e.g., Singapore) devoting a large fraction of all government spending to defence. However, the burden of defence on government spending appeared to be higher in the early 1990s than in the early 2010s, which corroborated our tentative conclusion that Indo-Pacific Asia was not experiencing an arms spending race.

${ }^{4}$ For example, the much publicised threat posed by the North Korea, and tensions between India and Pakistan or the nations bordering the South China Sea with competing claims in the Spratleys.

${ }^{5}$ Chinese GDP at PPP by 2016 was 14 per cent higher than that of the USA (CIA Factbook), while the technological lead of the USA with adversaries such as North Korea was also diminishing.

${ }^{6}$ The relationship between consumption and income has been observed as "one of the sturdiest" statistical regularities in macroeconomics (ibid: 465), while the representation of military expenditure as a national club good takes into account strategic considerations when modelled in an international/regional context (Gaibulloev, Sandler \& Shimizu, 2009).
} 
We therefore suggested that in order to illuminate the causal relationships involved in military capability formation, milex aggregates should be supplemented

with a set of physical indicators describing the nature of the investments being made by different military powers and what military options those investments give these powers, irrespective of their intent to exercise such options. Such indicators are implicit in the narrative in SIPRI's Yearbooks and in annual publications such as the IISS Military Balance. However, it would be useful to collect data for a set of standard measures that would facilitate the analysis of evolving military capabilities over time and assess them across different nations. In what follows we unpack the notion of military capability with a view to get a better understanding of changes in force structure and force readiness for deployment, which are often obscured by the highly aggregate nature of milex (ibid: 13).

In this paper we expand on the above theme as we aim to discuss a tentative spending monitoring framework within which military capabilities could be made more apparent. There are essentially two approaches that we consider in this paper. The top-down approach involves the disaggregation of milex into still highly summative but somewhat more functionally focused expenditure categories such as spending on Force-in-being, Future Force, Readiness, and Sustainment rather than the more common breakdown into spending on (environmentally-defined) Land Forces, Maritime Forces, Air Force, and so on. The bottom up approach starts with physical assets that have to be acquired, sustained over time, and kept in the desired state of readiness, e.g., Major Surface Combatants, Submarines, Air Combat Forces, or Ground Combat Forces. These categories of assets can then be assigned money values to form capability elements ${ }^{7}$, which also include expenditures on their sustainment and readiness. Examples of such capability elements are Capability for Major Surface Combatant Operations, Capability for Naval Aviation Operations, or Capability for Submarine Operations. Once these capability elements are defined and assigned money values they can be aggregated into broader categories such as the environment-related Maritime or Air Capabilities and used to compute stock and flow (milex) measures related to investment in the future force and sustainment of the force-in-being. We shall consider these two approaches in the following two sections.

This is not to suggest, however, that milex data reveal nothing at all about a nation's military capability or its strategic intent. By representing milex as government consumption of national resources we intended to highlight the "opportunity cost of military spending whether it is used as an insurance against and/or deterrence of potential hostile actions of foes, a contribution to collective security of allies and friends, or prudent investment in future force structure and leading to concomitant future consumption of national resources to provide national security" (ibid: 9). Consequently, in the Indo-Pacific Asia study we represented every nation in the region as a Westphalian nation-state, that is, as a sovereign national security agent with its government having a degree of discretion over the level of national military expenditure for given levels of milex by other nations. Milex appears to be useful in assessing defence spending of groups of two or more geographically proximate countries, described as allies/friends or potential foes, to determine their military interdependence (see, for example, Markowski \& Tani, 2005). The combined milex of countries seen as potential foes could then be interpreted as a measure of external threat, which may induce the focal country to increase its military expenditure to provide for its enhanced national security. Conversely, the combined milex of countries deemed to be friends and formal allies could induce the focal country to spend less on defence as military alliances offer their members some scale- and scope-related "membership" benefits but may also encourage some of them to free ride at the expense of other nations (Sandler \& Hartley, 2001; Sandler, 1993).

An important caveat should also be noted at the outset of the paper. There is a large body of classified information collected and maintained by a plethora of national military agencies as every country collects intelligence on military capabilities of countries perceived as potential adversaries and, usually, those regarded as close friends and allies. It is the job of military intelligence agencies to produce such data and it would be inappropriate, and indeed deeply worrying, if such information were to be available in public domain. Our interest is therefore confined to military data that can be made available through publicly accessible, open and verifiable sources. Such information is normally needed to facilitating the work of:

- $\quad$ security decision makers responsible for interpreting international trends in the evolution of national military capabilities, for deciding how those trends engage national interests, for judging whether those trends warrant a military response and for gauging how and the extent to which extant military capabilities need to be adjusted to protect national interests affected by the trends so identified;

\footnotetext{
${ }^{7}$ There is an obvious stock-flow problem that has to be addressed in this context. As we are interested in the Force-in-being as distinct from Future Force, the value of the Force-in-being specific to a particular accounting period, say a financial year, is largely the depreciation of capital assets plus the cost of personnel assigned to a particular capability element. Other expenditures will be assigned to either Readiness or Sustainment.
} 
- intelligence analysts responsible for advising decision makers about the evolution of other nations' military capabilities that engage the home nation's security interests;

- military capability practitioners responsible for advising policy makers about, firstly, the military implications of observed trends in the evolution of international military capabilities and about, secondly, international perceptions of the security implications of evolving home nation military capabilities;

- elected representatives of national taxpayers responsible for holding national security decision makers to account for the proper expenditure of taxpayers' dollars invested in developing home nation military capabilities in response to the evolution of international military capability;

- commentators contributing to national and international discourse about the nature and significance of trends in the evolution of domestic and international military capabilities; and

- scholars involved in analysing the economic, political and strategic significance of domestic and international expenditure on military capability.

It is these people who tend to lead the public discourse on matters related to national and international security and who are often influential public opinion makers. It is therefore important that information available in public domain is more revealing than the aggregate military expenditure data, which are presently collected and published by international research bodies such as the Stockholm International Peace Research Institute (SIPRI).

SIPRI has been the preeminent producer of milex data for over 50 years. It is therefore instructive to remind ourselves why it was established in 1966 and the rationale behind its founding. It was

the provision of impartial data and information on armaments to be used as a solid basis for disarmament proposals and negotiations. ... By the time SIPRI was established, the mission of impartial data provision also encompassed [in addition to nuclear weapons] biological and chemical weapons, international arms transfers, and military expenditures.... [The milex data was, thus, produced by SIPRI] "as an indicator of inputs - of financial resources - into the military sector rather than of outputs - such as military capability or strength. For example, military aid is included in the data for the donor country and excluded from that of the recipient country (Perlo-Freeman \& Sköns, 2016: 5-6).

SIPRI's military expenditure data series have offered a perspective on trends in military spending and its opportunity cost in terms of the burden of defence (the share of GDP ultimately borne by the taxpayer) and the proportion of government expenditure that is diverted to defence away from other areas of public goods provision. As Perlo-Freeman and Sköns note, milex has also been seen "as an indicator of governments" political priorities between various purposes" (ibid: 6).

While much of the subsequent use of milex data by economists has involved investigation of the relationship between milex and economic growth, the original purpose of the provision of impartial information on armaments to be used as a factual basis for disarmament proposals and the maintenance of global peace remains paramount. Ultimately, milex involves spending on the development and sustainment of lethal force which could be used offensively as well as defensibly against other nations and as a means of internal repression. Thus, military expenditure should be monitored internationally both as a contribution to early stages of conflict resolution and as an early warning of military build-ups. This requires not only the continuous focus on data quality improvement but also some disaggregation of the milex data to capture those aspects of expenditure on the formation of military capabilities, which may have potentially significant implications for international armed conflicts. Perlo-Freeman and Sköns (ibid: 11) suggest two major priorities for the broadening of the SIPRI military expenditure project:

- the provision of disaggregated expenditure data, initially covering a shorter period, by function such as: personnel, operations and maintenance, procurement, $\mathrm{R} \& \mathrm{D}$, and construction; and

- the inclusion of civil security expenditure in the spending data to provide a broader perspective on national security expenditure.

Other extensions may include the inclusion of spending on paramilitary forces that are or might be assigned military functions and on military pensions to give a better indication of the through-life cost of military personnel. The main purpose of this paper is to argue the case for the broadening of the SIPRI database to support research which probes in more depth the often fragile foundations of global peace.

Accordingly, the paper is structured as follows. In the next section we discuss the scope for the top-down disaggregation of milex. This is followed by the discussion of the bottom-up approach in section 3 . We conclude the paper with some suggestions for future development of appropriate data databases.

\section{Military Capability: Top Down Disaggregation of Milex}

As the need to deploy military force is normally contingent on the occurrence of a particular state of the world that requires or justifies its use, an intermediate product (output) of a national military organisation can be described as the ability (capability) to: prosecute operations against a source of military threat; undertake actions to take advantage of a 
particular military opportunity; or provide assistance to civil authorities in non-military contingencies (for a discussion see Tellis, Bially, Layne \& McPherson, 2000, ch. 7). In short, 'military capability' can be defined as the capacity of an extant military force to achieve a military effect. Such capacity is a function of the structure of that force (including military artefacts and the personnel trained to operate them), the readiness of that force to undertake the task intended to achieve that effect, and the time for which that force can sustain operations pursuant to that task. National military capabilities are generated through the purposeful orchestration of functional inputs such as command and management, personnel, organisation, weapons systems, facilities, supplies and other forms of support for force formation and use. Annex 1 provides an example of such capability inputs in the Australian defence practice.

As all military organisations are largely service providers rather than producers of artefacts, a large part of their service provision is only directly observable when particular military or civil contingencies arise. Pending the occurrence of these contingencies, military organisations are producers of mostly intermediate products in the form of capability elements or assets that have the capacity to generate the required military/civil effect or output (e.g., prosecute combat operations or respond to a civil emergency), if and when necessary. A country may utilise these capabilities to defend itself against military threats, project military power beyond its borders, or assist its civil and international society in non-military contingences. Given the contingent nature of military deployments, assets that form military capability elements have to be sustained over time and maintained in the required state of readiness to be used if and when required for the intended operational duration. However, the concept of capability also allows for an element of stretching the use of assets that comprise it to achieve previously unanticipated effects. That is, by their very nature, the utility of operational capabilities is not fully known before their operational deployment as military operations are largely characterised by surprise and operational innovation. Thus, the true scope of military capability can only be ascertained when it is tested in anger against a real adversary or when it is deployed to assist civilians in a real civil emergency.

Not surprisingly, capability elements are difficult to describe precisely, measure and value. In principle, the value of an element of military capability is the value imputed to a stream of services that this bundle of assets might be expected to produce over its lifetime providing that certain contingencies materialise and require periods of asset deployment and, thus, the actual military service provision. In a somewhat simplistic representation, the value of a quantum of military capability can be expressed as the expected net present value of (contingent) military and civil operations, which this capability element is called upon to prosecute when required, weighted by the corresponding probabilities of these operations actually occurring. ${ }^{8}$ Theoretically and in its simplest form, this may be represented as:

$$
C=\sum_{t=1}^{\infty} \sum_{i=1}^{I} \pi_{i}(t) E_{i}(t) \rho^{-t},
$$

where ' $C$ ' denotes an element of military capability, ' $t$ ' indexes time and 'i' prospective event, $\pi[0,1)$ the probability of event ' $i$ ' occurring, ' $E$ ' the monetary value attached to the event, and $\rho(>1)$ is the discount rate. This capability assessment would realistically also include the expected net present value of a contribution made by this capability element to successful deterrence of military threats, i.e., its contribution to national investment in military capability that results in certain threats being removed altogether or their likelihood of occurrence mitigated. Given the complexity of such assessments, the valuation of military capability elements as depicted in equation (1) tends to be intuitive rather than formal. The calculation therefore is more in the realm of value judgements rather than in the form of precise value calculations as depicted in equation (1) above.

As military capabilities are intermediate rather than final products of military investment, it is arguable whether they should best be described as inputs or outputs. ${ }^{9}$ By disaggregating milex into more specifically hypothecated areas of functional military expenditure, the latter are treated as inputs. This approach is implicit in fundamental inputs to capability formation shown in Annex I. This, we believe, is also the approach underlying the disaggregation of milex into sub-categories by the member states of NATO and that adopted by the European Defence Agency (EDA) for its 27 member states (European Defence Agency [EDA], 2016).

NATO defines defence expenditure as payments made by allied national governments specifically to meet the needs of

\footnotetext{
${ }^{8}$ This does not mean that the outcome of military operations prosecuted under threat is necessarily favourable so that the value imputed to military capability would only be positive if the military entity prevails in military contingencies, successfully deters potential threats, or performs adequately in response to civil emergences.

${ }^{9}$ For example, in their conceptual discussion of warfighting capabilities, the RAND Corporation regards measures of military capability "as "input measures" in the specific sense used by Stephen Biddle: they focus on understanding what "goes into" the making of an effective national military capability and how such effectiveness can be compared across countries in a comparative-static sense without either doing any military balance analysis or pretending that it can explain how any given force-on-force encounters will actually turn out in practice" (Tellis et al., 2000:134).
} 
its armed forces or those of Allies (North Atlantic Treaty Organisation [NATO], 2017). The expenditure is reported under the following four main categories:

- $\quad$ Equipment,

- $\quad$ Personnel,

- Infrastructure, and

- Other.

Annex II contains details of expenditure aggregation into these four categories. A major component of military expenditure is payments on Armed Forces financed within the Ministry of Defence (MoD) budget, where Armed Forces include Land, Maritime and Air Forces and various joint formations such as Administration and Command, Special Operations Forces, Medical Service, Logistic Command, and so on (NATO, 2017). The figures may also include expenditure on 'other forces' like Ministry of Interior troops, border guards, national police forces, customs, gendarmerie, carabinieri, coast guards, and so on. "In such cases, expenditure should be included only in proportion to the forces that are trained in military tactics, are equipped as a military force, can operate under direct military authority in deployed operations, and can, realistically, be deployed outside national territory in support of a military force" (ibid). Military-related expenditures financed through the budgets of ministries other than MoD should also be reported as defence expenditure (ibid). For example, pension payments made directly by the government to retired military and civilian employees of military establishments should be included regardless of whether they are made from the MoD budget or by other ministries. On the other hand, expenditures on NATO joint infrastructure is included in the total defence expenditure of each NATO country but only to the extent of that country's net contribution while war damage payments and spending on civil defence are both excluded from the NATO definition of defence expenditure (ibid). ${ }^{10}$

The EDA expenditure categories (in $€$ ) include spending on:

- Personnel,

- Operations and maintenance,

- Defence investment,

- Equipment procurement,

- Defence R\&D,

- Defence R\&T,

- Infrastructure/construction,

- Defence outsourced,

- Operations (deployed).

Most of the above categories reflect the (investment) expenditure on force structure primarily to pay for military human capital in use and the acquisition of equipment and consumables.

In addition, there is a category of "collaborative expenditure" reflecting the cost of equipment procurement and R\&T shared by different groups of EDA member states. The above expenditure categories are supplemented by physical measures giving some indication of force 'deployability' (as a measure of readiness), expressed as a ratio between the military personnel deployed in crisis management operations to the remaining military personnel as well as data on deployable and sustainable (land) forces:

- average number of troops deployed;

- total number of deployable land force personnel; and

- total number of sustainable land force personnel.

These spending categories, as defined by NATO and EDA statisticians, represent cost outlays and do not naturally map into military capability elements. Milex reflects the costs associated with the acquisition of new equipment and additions to stocks of consumables, current outlays on maintenance of equipment and facilities, the current military wage bill, current outlays on training and other current outgoings, including pensions. All these are flow categories of expenditure incurred during the current fiscal year or a particular accounting period. However, the armed force's

\footnotetext{
${ }^{10}$ Similarly, expenditure for peacekeeping and humanitarian operations (paid by $\mathrm{MoD}$ or other ministries), the destruction of weapons, equipment and ammunition, and the costs associated with inspection and control of equipment destruction should all be included in defence expenditure. Research and development (R\&D) costs should also be included in defence expenditure, including those R\&D projects, which have not resulted in production of equipment. Expenditure for the military components of mixed civilian-military activities should be included, but only when this military component can be specifically accounted for or estimated. Finally, financial assistance by one Allied country to another, specifically to support the defence effort of the recipient, should be included in the defence expenditure of the donor country and not in the defence expenditure of the receiving country (ibid).
} 
potential to use force derives from the stock of military assets it has accumulated through its past and current investments (force structure), from the readiness of those assets for deployment to achieve the desired military effect, and from their ability to sustain the military effect over the required period of time once is deployed. Current expenditures on new equipment acquisition and military consumables may only provide a very limited perspective on the accumulated stocks of military hardware and consumables. In the absence of conscription and large reserves of trained personnel, military wage bill offers a better measure of the current stock of military personnel. Nevertheless, limited disaggregation of milex provides an indication of current investment levels in force structure, its readiness and sustainability. For example, EDA categories such as 'personnel', 'defence investment' and 'equipment procurement' provide some insights into the relative weight of military and civilian personnel while the combined 'operations and maintenance' expenditure servers as an indication of the relative readiness and sustainability of the armed forces. Per $s e$, these are hardly imperfect measures of military capability but year-to-year changes in these categories offer a better perspective on how milex contributes to the development of force structure and its readiness-cum-sustainment. For example, the increased spending on equipment procurement in any given year may reflect the cyclicality of force modernisation or a sustained build-up of military capability. A glance at the time series of equipment procurement data and year-to-year changes in such expenditure is likely to be more revealing even if the quality of annual data is poor. Thus, even a limited disaggregation of national milex is useful providing that data is collected on a consistent basis over time and, for international comparisons, across a number of countries. Both NATO and EDA milex disaggregations are good examples of this approach.

The budgetary process appears to favour the top-down disaggregation of military expenditure. As the defence budget is only a component of the all-of-government budget (and the associated forward estimates of expenditure), the aggregate military spending is often determined as a part and parcel of the annual, all-of-government budgetary cycle and the military may only have a limited discretion in influencing the overall size of defence vote. They are likely to have more discretion though in influencing the distribution of the vote between spending on the force structure enhancements, readiness and sustainment and would alert the government to physical implications of the milex target for the force-in-being and investment in future force. In practice, budgetary processes tend to be iterative with an initial expenditure limits fixed by the Treasury top down to be subsequently challenged by spending ministers, adjudicated by the cabinet and fixed again by the Treasury; with the process repeated until a broadly satisfactory division. Such an iterative process is shown in Figure 1.

In the figure, two axes represent expenditure on two measures of force structure, $F_{1}, F_{2}$, that is, expenditure on new equipment and infrastructure procurement and expenditure on personnel respectively, and the third axis shows the combined expenditure on force readiness and sustainment, $\mathrm{R}+\mathrm{S} .{ }^{11}$ The triangular budget plane, shown by the broken line $\mathrm{Abc}$, represents the allocated or proposed defence budget constraint, $\mathrm{ME}_{\mathrm{t}}$ in fiscal year $\mathrm{t}$, and its inclination reflects the relative costs (or shadow prices) of the three components of milex (financial trade-offs between the three capability elements). Thus, a point on the expenditure plane abc, represents a particular combination of spending on force structure, readiness and sustainment of the armed forces, for example point * represents the combination $\left(\mathrm{F}_{1} \mathrm{~F}_{2} \mathrm{R}+\mathrm{S}\right)^{*}$. In budget approval cycle, the government may determine the overall amount of military expenditure, say, by fixing the milex budget target $\mathrm{ME}_{\mathrm{t}}$ for year $\mathrm{t}$. For example, NATO allies are urged to spend at least two percent as their real GDP in the form of real military expenditure. If this is a realistic target and a binding constraint, the managers of the defence portfolio would explore alternative ways of spending the allocated budget by assessing different combinations of the three capability elements, $F_{1}, F_{2}$, and $R+S$ and selecting the one that best meets their force planning objectives.

${ }^{11}$ As milex is essentially an annual flow measure, $F_{1}$ represents the value of financial resources expended during a particular fiscal year to make equipment and infrastructure additions to the force in being. $F_{2}$ is the annual personnel wage bill plus the other, related expenditure on personnel training and sustainment. This may also include the cost of paramilitary units and annual expenditure on military reserves. $\mathrm{R}+\mathrm{S}$ represents the annual expenditure on the force operating costs and other spending related to force readiness and sustainment. 


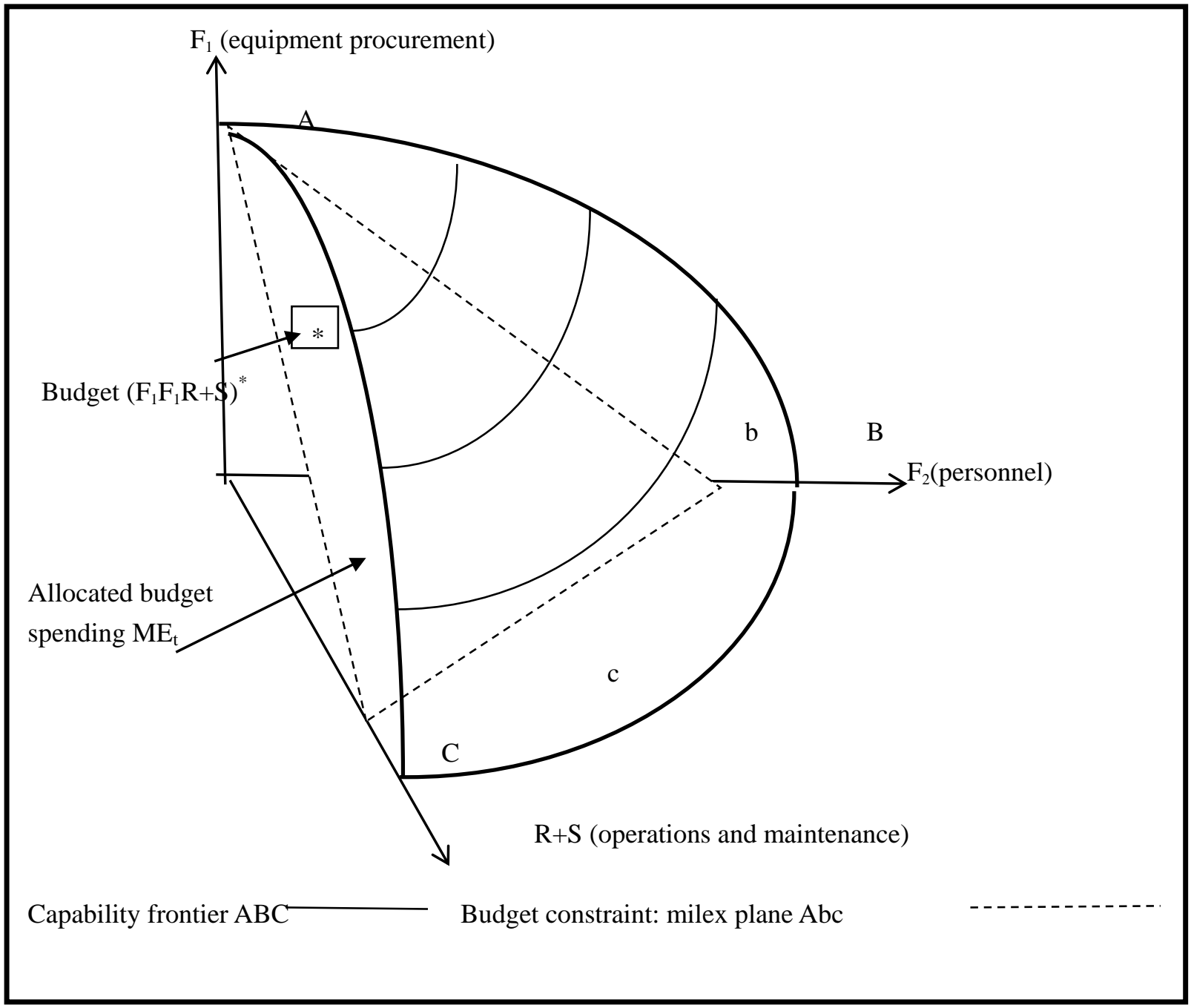

Figure 1. Disaggregation of milex into force structure, readiness and sustainability

Assuming that all of $\mathrm{ME}_{\mathrm{t}} *$ is to be spent and there is no budget supplementation, they assess different spending options located on the surface of the budget surface Abc to find the preferred combination of $F_{1}, F_{2}$, and R+S. That latter could have been shown as the point of tangency between the budget surface Abc and the highest accessible preference surface (a three dimensional equivalent of a standard, two dimensional preference curve). (This has not been shown to avoid the crowding of the figure with too many concepts but it is intuitively familiar, standard geometry used to illustrate the constrained maximisation problem for a resource user or an investor maximising utility subject to their budget constraint.) Once the defence planners determine their preferred capability structure, $\left(\mathrm{F}_{1} \mathrm{~F}_{1} \mathrm{R}+\mathrm{S}\right)^{*}$, they submit it to the government for approval and when it is approved it becomes the actual defense budget for year $t, B\left(F_{1} F_{1} R+S\right)_{t}^{*}$. In this decision-making framework national resources are provided to the military resource managers, who are responsible for transforming these financial resources into intermediate products that are the country's military capabilities. Given the budget constraint, the distribution of resources between the three sub-areas of expenditure would reflect the most desirable/credible configuration of perceived military threats and allied military effort that generally shape each country's defence architecture.

In addition, Figure 1 shows a concave defence (production) capability possibility frontier ABC (which resembles a spinnaker sail of a sailing boat). This represents different combinations of the three capability elements that are feasible to produce, as opposed to finance, during the fiscal year under consideration. For simplicity, it is assumed that these each of the capability elements includes both domestically-produced and imported components. Thus, military equipment, $F_{1}$, may be procured from domestic or foreign suppliers and personnel may be drawn in-country or hired from abroad. As drawn, the budget constraint surface is located within the capability possibility frontier, which suggests that it is a binding constraint separating combinations of the three capability elements that are feasible to produce but not feasible to finance (located on or below the frontier $\mathrm{ABC}$ but above the budget surface Abc). Only those 
combinations of $\mathrm{F}_{1}, \mathrm{~F}_{2}$ and $\mathrm{R}+\mathrm{S}$ that are located on or below the budget surface are both feasible to produce and to fund. All combinations of the three capability elements which are located above the possibility frontier ABC are no feasible to produce. The exact position of the frontier reflects not only the domestic production potential and potential imports but also the government's local content policy. For example, when a large portion of the required military capability has to be sourced domestically as a matter of government policy, the ABC frontier shifts inwards. Similarly, military alliances, such as NATO, shift the frontier to the right as more resources are accessible. It is also possible that the allocated military budget is too ambitious to be achieved given the potential of the home economy and accessible imports (the $\mathrm{Abc}$ budget surface is located above the $\mathrm{ABC}$ frontier). Thus, financial resources available to the military may be waisted if the capacity to absorb them is limited or if the government insists on physical spending targets that meet its civil objectives but not the military requirements (e.g., the government fixes a point on the budget surface Abc different from the combination preferred by the military planners, $\left.\mathrm{F}_{1} \mathrm{~F}_{1} \mathrm{R}+\mathrm{S}\right)_{\mathrm{t}}^{*}$.

In reality, the budgetary process may be quite complicated with some items of expenditure largely predetermined by prior spending commitments and the government using military spending for non-military purposes such as regional or industry assistance. However, as we are primarily interested in international comparisons of military spending, both NATO and EDA have shown that it is possible to obtain milex data disaggregated one level of indenture down and, over time, the disaggregation reflects national priorities regarding the distribution of milex between personnel, equipment procurement and infrastructure, and operations and maintenance.

For all its limitations, some milex disaggregation is likely to be more revealing than no disaggregation at all. Relatively large changes in $F_{1}$ may suggest a bias of investment in favour of future force although armed forces often invest in new platforms, fitted for but not with new weapons systems, to avail themselves of an option to experiment with technology demonstrators and expand in future if need be. However, accelerated spending on both $F_{1}$ and $F_{2}$ may be more revealing about a country's strategic intent. Similarly, a simultaneous increase in spending on Readiness and Sustainment may suggest greater imminence of or a higher priority assigned to military operations. Readiness and sustainment are often left underinvested in unless the likelihood of using the force-in-being in military operations is high. Increasingly, the lead-time required for the procurement and operational diffusion of technologically sophisticated weapons systems exceeds the tactical warning time available for operational deployments, thus, making contemporary military operations "come as you are" affairs. Measures of readiness and sustainability, even if crude and indirect, may therefore reveal more about the imminence of military activity and military intent than investments in increments to stocks of equipment for future force. ${ }^{12}$ Overtime, changes in variables, albeit crudely constructed, are also revealing as the consistency in measures may itself be quite informative. Thus in terms of equation (1),

$$
\Delta C_{t}=\Delta E_{i}(t)
$$

where $\Delta$ denotes percentage change in the respective variable and ' $i$ ' is restricted to elements judged to be relevant at time ' $t$ ' as explained in the next section.

The annual compilation of national military expenditures produced and published by the Stockholm International Peace Research Institute (SIPRI) is a prominent example of the most aggregate financial perspective on inputs to military capability. The milex methodology developed by SIPRI is now mature and could be adapted to provide a more granular approach outlined in the previous section. The granularity of the milex methodology could also be increased by relating military expenditure to main organisational-cum-functional elements of the armed forces, say, along the conventional distinction between the Air Force, Navy and Army organisational elements. There limits to further top-down disaggregation as to achieve more granularity the bottom-up analysis is likely to be more effective.

\section{Military Capability: Bottom - Up Aggregation of Capability Components}

An alternative approach to milex disaggregation would involve the interpretation of intermediate military products (capabilities) as outputs. The notion of military capability as an output of the country's defence effort is premised on the understanding that the military receives a quantum of national resources to transform it into specific warfighting and civil assistance capacities, which are only used and their true potential is fully revealed if certain contingencies arise but

\footnotetext{
${ }^{12}$ For the purpose of international comparisons measures such as $\mathrm{R}+\mathrm{S}$ are least satisfactory as the annual cost of operations and asset maintenance is a poor proxy for time-related measures such as the mean time to deploy the force or the mean time to sustain it in deployment. Ultimately, time-related measures could perhaps be produced by panels of military experts who would use their professional judgement to determine the lead time needed to deploy a target percentage of the total personnel and the likely maximum duration for which this quantum of force could be deployed to produce a particular military effect Many international indices, such as the World Competitiveness Index, use a combination of 'hard' statistical data and 'soft' measures derived from expert opinion combined using weights that usually favour the hard data.
} 
which can nevertheless be described and measured ahead of their potential deployment. For example, these intermediate outputs/capabilities can be described in terms of physical quantities of force structure elements, e.g., the size and composition of units comprising the military force, categories of equipment and their order of battle, and possibly some description of technology embedded in military hardware (e.g., nuclear vs conventional submarines). For each of these force structure elements the corresponding measures of readiness and sustainability could also be prescribed as measures of the elapsed time needed to deploy a particular capability element and the expected duration of this deployment. These capability elements could then be costed and the cost figures added together to provide the dollar value of each capability element or, as it is sometimes labelled, 'capability output'. In contrast to milex, which measures the actual flows of expenditure, these capability outputs are stock measures, i.e., they describe, at a point in time, the cost incurred to acquire a particular quantum of military resources, which are kept in a prescribed state of readiness and, if needed, could be sustained in use over a prescribed period of time. The values of capability outputs could then be further aggregated into broader categories, say, reflecting their anticipated operating environment: Land, Maritime, Air, Space, Cyberspace; or the organisational framework of the armed forces, e.g., Army, Navy, Air Force, Intelligence, Command H/Q; or their military functional characteristics: Strike, Manoeuvre, Logistics, Intelligence, Command and Control.

The bottom up approach resembles the capability outputs approach used by the Australian Department of Defence in the early 2000s (Annex III illustrates). In the then Australian DoD classification "capability outputs" were aggregated into "outcomes" - a rather misleading concept implying the ultimate end product rather than an aggregate intermediate output. It was not clear, however, how these component capability outputs were actually calculated. It would be challenging, to say the least, to try to adapt this intermediate output framework measured in either physical units (such as personnel days, flying hours or steaming miles) or in money terms to collect a consistent set of international statistics suitable for assessments of changes in force structure and readiness/sustainment capabilities between different countries. ${ }^{13}$ Nevertheless, the Australian DoD's output framework shown in Annex III is indicative of how the inherently input-based data could be represented - in our view inappropriately - as intermediate or final outputs.

In contrast, the Australian DoD's ten-year Defence Capability Plan has been by far more useful managerial planning tool and a decision support aid in many ways more resembling the bottom up approach and the intermediate output logic (Department of Defence [DoD], 2016). The Plan covers, inter alia, six "capability streams", which are used in the Integrated Investment Program to represent the key elements of the future force. ${ }^{14}$ The capability streams convert into six categories of "Defence (intermediate) military outputs" (same descriptors are used for both), or capabilities:

- Decision Making Superiority (including intelligence, surveillance, reconnaissance, electronic warfare, space and cyber);

- Key Capability Enablers (including airfields, wharves, port facilities, ADF bases and logistics systems, weapons ranges, training facilities, science and technology programs, and so on);

- Air and Sea Lift (including multi-purpose vessels, refuelling aircraft, replenishment/supply ships, search and rescue, transport aircraft, utility helicopters);

- Maritime and Anti-submarine Warfare (including maritime support and reconnaissance, major surface combatants such as destroyers and frigates, submarines, minor war vessels);

- Strike and Air Combat (including air and missile defence, airbases, airborne early warning and control, electronic warfare, light helicopters); and

- Land Combat and Amphibious Warfare (including amphibious elements, barracks and training ranges, helicopters and armed aircraft, ground combat, land communication, special operations, electronic warfare and intelligence, armour and vehicles).

This functional capability framework provides a basis for representing the force structure as a bundle of intermediate products (capabilities), which could be deployed to generate specific military effects (outputs) if particular contingences arise. More specific categories of assets comprising each group of functional outputs could also be measured in physical units such as ship steaming days. It could therefore be possible to use aggregate measures of ship steaming days to

\footnotetext{
${ }^{13}$ The bottom-up approach illustrated in Annex III was developed as a public sector management support methodology to enhance the efficiency of managerial decision-making by shifting the emphasis from spending and inputs to outputs and outcomes/impacts of public expenditure.

${ }^{14}$ The Integrated Investment Program was developed through a comprehensive Force Structure Review that assessed Australia's defence capability needs into the 2030s. A major objective of the Review was to ensure that key enablers of capability such as wharves, airfields, training areas and bases, information and communications systems, and supporting science and technology were also accorded appropriate priority in Defence investment decisions. The Investment Program covers investment intentions over the decade to $2025-26$.
} 
describe and measure, for example, "maritime and anti-submarine warfare" capability for the range of platforms and assets comprising this capability stream. Alternatively, intermediate output categories could be disaggregated into stocks of physical military assets (e.g., a number of platforms comprising the maritime and anti-submarine warfare capability) and vectors of data reflecting their intended operational use (e.g., steaming hours for each category of platforms). ${ }^{15}$

In this framework, military capability outputs comprising the capability plan are not derived from the milex data. They are developed, prioritised and costed by military managers, bottom up, as desirable military capabilities that are listed as "must have" or "nice to have" capabilities to be approved by the government and endorsed by its financial managers. The affordability of the desired capability outputs need to be verified by relating them to forward estimates of the corresponding budget items. To be realistic though they will need to be aggregated into forward estimates of military budgets and, thus, they would influence both the size and composition of future milex streams (on the understanding that actual military expenditures at the time of military contingencies would require budgetary supplementation over and above the projected peacetime spending).

In domestic context, the top down and bottom up approaches converge as capability plans cannot be developed without an implicit recognition of financial affordability of the desired military capabilities while budgetary cycles should take into consideration capability development plans developed by different spending portfolios to guide their long term investments. In principle, it should also be possible to disaggregate the budgeted military expenditure into the above six functional categories to link annual spending to the six military capability streams, thus, relating annual flow data to stocks of intermediate outputs. In future, the increased availability of accrual accounting budgetary data could provide more opportunities for measuring the value of stocks of military capital and another useful indicator of the burden of defence if such indices as the share of military assets in all government assets (or some measure of national wealth) could be developed.

As the purpose of this paper is to review the potential for complementing the milex data with more detailed information suitable for international assessments of military capabilities and intentions, we need to ask what quality requirements such data should comply with to be fit for this purpose. We suggest that they should be: timely (subject to short production lags); internationally portable, i.e., capable of consistent application across a very diverse range of countries; verifiable; and easy to collect. The two aforementioned sources of disaggregated milex data, NATO and EDA, both meet all these criteria and set the benchmark for what is likely to doable across a broader group of nations. The bottom up approach is by far more ambitious and to achieve the desired quality standards would need to rely on costly cooperation between the data producers and all military and statistical entities responsible for the collection and verification of primary data. Thus, the initial disaggregation of milex into expenditure on personnel, investment in equipment and facilities (including military R\&D) and force readiness and sustainment appears to offer the best way forward. This is largely similar to the current structure of data produce by NATO for its member states (see NATO, 2017). To go beyond the NATO format, the 'investment' category could be subdivided into: equipment procurement, facilities and infrastructure and R\&D.

\section{Conclusion}

If the contemporary geo-political discourse is any guide, the international strategic environment has become more contested than at any time since the end of the Cold War. In this increasingly febrile environment the availability of and access to impartial and high quality data on military capability formation will become increasingly important to effective security management. In the past, it was SIPRI's stated task to conduct "scientific research on questions of conflict and cooperation of importance for international peace and security with the aim of contributing to an understanding of the conditions for peaceful solution of international conflicts and for a stable peace". The SIPRI milex database has been a major source of impartial, quality information on military spending. We believe that the recently revised SIPRI milex database could become a prompt for a new direction in the evolution of publically available information on military capability formation. As we argued previously, an aggregate measure such as milex masks analytically vital details about the spending on technology, hardware, personnel, and the readiness and sustainability of armed forces. It is these components of military spending that underpin military capability. We therefore propose that the milex data are disaggregated one step down to differentiate between investments in the future force and expenditure on the readiness and sustainment of the force in being. In particular, it is the readiness and sustainment that provide a leading indicator of whether and how soon the extant stock of military assets could be deployed in anger.

\footnotetext{
${ }^{15}$ Such as stocks of military equipment monitored regularly by the International Institute of Strategic Studies (IISS). That said; even if numbers of certain categories of equipment are known, crude stocktakes tend to miss out on the quality of force upgrading emanating from various acquisitions. This can be a serious deficiency in an area where technological progress is rapid and when the new platforms are often fitted for but not with various armaments.
} 


\section{References}

Australian Government. (2016). 2016 Defence White Paper. Commonwealth of Australia available at http://www.defence.gov.au/whitepaper/Docs/2016-Defence-White-Paper.pdf (accessed 7 March 2016).

Australian Government. (2016). 2016 Integrated Investment Program. Commonwealth of Australia available at http://www.defence.gov.au/WhitePaper/Docs/2016-Defence-Integrated-Investment-Program.pdf (accessed 7 March 2016).

Blinder, A. S., Deaton, A., Hall, R. E., \& Hubbard, R. G. (1985). The time series consumption function revisited. Brookings Papers on Economic Activity, 465-521. https://doi.org/10.2307/2534444

Brauer, J. (2002). Survey and review of the defense economics literature on Greece and Turkey: What have we learned?. Defence and Peace Economics, 13, 85-108. https://doi.org/10.1080/10242690210969

Bruce, N. (1990). Defence expenditures by countries in allied and adversarial relationships. Defence and Peace Economics, 1, 179-195. https://doi.org/10.1080/10430719008404661

CIA Factbook. CIA World Fact Book. On-line: https://www.cia.gov/library/publications/the-world-factbook/(accessed on 24/01/2016).

Department of Defence. (2012). Australian Defence Capability Development Handbook. Canberra: Commonwealth of Australia.

Department of Defence. (2016). Integrated Inwestment Program. Canberra: Commonwealth of Australia.

Dunne, P. J., \& Nan, T. (2016). Military expenditure and growth, 1960-2014. The Economics of Peace and Security Journal, 11(2), 50-56. https://doi.org/10.15355/epsj.11.2.50

Dunne, P. J., \& Smith, R. P. (2007). The Econometrics of Military Arms Races. in Sandler, T. and Hartley, K. (Eds.). Handbook of Defense Economics, Defense in a Globalized World, 2(28). Handbooks in Economics 12. North-Holland, Elsevier: 913-940.

Dunne, P. J., Smith, R. P., \& Willenbockel. (2005). Models of Military Expenditure and Growth: A Critical Review. Defence and Peace Economics, 16(6), 449-461. https://doi.org/10.1080/10242690500167791

EDA. (2016). National Defence Data 2013-2014 and 2015 (est.) of the 27 EDA Member States. Silvija Guzelyte,

Policy Officer Defence Data Analysis, Brussels: European Defence Agency.

Gaibulloev, K., Sandler, T., \& Shimizu, H. (2009). "Demands for UN and non-UN peacekeeping: Nonvoluntary versus voluntary contributions to a public good". Journal of Conflict Resolution, 53(6), 827-852. https://doi.org/10.1177/0022002709338509

Hartley, K., \& Sandler, T. (Eds.). (1995). Handbook of Defense Economics, 1. Handbooks in Economics 12. North-Holland, Elsevier.

McGuire, M. C. (2007). Economics of Defence in the Globalized World. in Sandler, T. and Hartley, K. (Eds.). Handbook of Defense Economics, Defense in a Globalized World, 2, Handbooks in Economics 12. North-Holland, Elsevier: 623-648.

Markowski, S., Chand, S., \& Wylie, R. (2017). Economic Growth and Demand for Military Expenditure in the Indo-Pacific Asia Region, Defence and Peace Economics. https://doi.org/10.1080/10242694.2016.1274059

Markowski, S., \& Tani, M. (2005). Defence Expenditure, Spill-ns and Threats in Asia-Pacific, 1985-2001. Defense and Security Analysis, 21(3), 243-265. https://doi.org/10.1080/0743017052000344938

Medcalf, R. (2013). The Indo-Pacific: What's in a Name?". The American Interest, 10(2), 58-66.

NATO. (2017). Defence Expenditure of NATO Countries (2009-2016). Brussels: Public Diplomacy Division, Press Release PR/CP(2017)045. March.

PBS (2004). Portfolio Budget statements 2004-05: Defence Portfolio. Budget Related Paper Nos. 1.4A and 1.4C. Department of Defence and the Defence Housing Authority. Canberra

Perlo, F. S., \& Sköns, E. (2016). Snakes and ladders: The development and multiple reconstructions of the Stockholm International Peace Research Institute's military expenditure data. The Economics of Peace and Security Journal, 11(2), 5-13.

Posen, B. R. (2003). "Command of the commons: the military foundation of US hegemony". International Security, 28, 5-46. https://doi.org/10.1162/016228803322427965 
Potts, J. (2000). The New Evolutionary Microeconomics: Complexity, Competence and Adaptive Behaviour, Cheltenham: Elgar.

Sandler, T. (1993). "The Economic Theory of Alliances". Journal of Conflict Resolution, 37(3), 446-483. https://doi.org/10.1177/0022002793037003003

Sandler, T., \& Hartley, K. (1995). The Economics of Defense,Cambridge Surveys of Economic Literature. Cambridge: Cambridge University Press.

Sandler, T., \& Hartley, K. (2001). Economics of Alliances: The Lessons for Collective Action. Journal of Economic Literature, XXXIX(September), 869-896. https://doi.org/10.1257/jel.39.3.869

Sandler, T., \& Hartley, K. (Eds.). (2007). Handbook of Defense Economics, Defense in a Globalized World, 2, Handbooks in Economics 12. North-Holland, Elsevier.

Sandler, T., \& Hartley, K. (2007). Defense in a Globalized World. in Sandler, T. and Hartley, K. (Eds.). Handbook of Defense Economics, Defense in a Globalized World, 2(20). Handbooks in Economics 12. North-Holland, Elsevier: 607-622.

Smith, R. (1995). The Demand for Military Expenditure. in Hartley, K. and Sandler, T. (Eds.) Handbook of Defense Economics, 1(4), Handbooks in Economics 12. North-Holland, Elsevier, 69-88.

Smith, R. (2009). Military Economics, The Interaction of Power and Money. London: Palgrave Macmillan.

Tellis, A. J., Bially, J., Layne, C., \& McPherson, M. (2000). Measuring National Power in the Postindustrial Age. Monograph Report MR-1110-A, RAND Corporation.

World Bank. (2015). World Development Indicators. on-line: https://blogs.worldbank.org/opendata/release-world-development-indicators015 (accessed on 24/01/2016).

\section{Annex I}

Fundamental inputs to military capability formation as applied in by Australian Defence

a. Personnel inputs to capability include consideration of recruiting, conducting individual training, and developing and retaining the necessary people with appropriate core skills to meet Defence needs. Personnel includes all people within Defence, both military (permanent and reserves) and civilian. In developing capability proposals, projects must clearly define what workforce (from Defence and industry) will be required when, and with what competencies and skill sets;

b. Organisation is the appropriate personnel establishment, balance of competencies and structure to accomplish Defence tasks and to ensure appropriate command and control. This provides the underpinning structure for Defence.

c. Collective training applies across combined, joint, single service and unit levels. To optimise performance, organisational elements must undertake a comprehensive and ongoing collective training regime validated against the preparedness requirements for operations, derived from Government guidance.

d. Major systems include significant platforms, fleets of equipment and operating systems designed to enhance Defence's ability to engage military power. Major systems are core components of capability, and often comprise systems of principal items in their own right, or equipment which regularly requires more detailed reporting and management.

e. Supplies must be available for units and force elements to conduct the necessary training activities and ongoing administrative tasks required for an operational level of capability. Stocks must be able to be supplied within readiness notice to achieve the operational viability period and ongoing sustainment of tasks required by the operational preparedness requirement. This may necessitate the holding of reserve stocks where provisioning lead times are beyond the readiness notice.

f. Facilities and training areas include buildings, structures, property, plant, equipment, training areas, civil engineering works, base support areas and associated through-life maintenance and utilities necessary to support capabilities, both at the home base and at deployed locations. Training areas include any area of land, sea, undersea or air that may be designated for military manoeuvres or simulated wartime operations involving planning, preparation and execution, carried out for the purpose of training and evaluation. Training areas may contain a variety of ranges within their boundaries. Ranges include all air, land and/or sea areas used for Defence live-firing weapons practices, tests or operations. Training areas also contain facilities and infrastructure that support training.

g. Support includes infrastructure and services that are integral to the maintenance of Defence effort in Australia and worldwide to support deployed Defence capability. It includes, but is not limited to, training/proficiency support; supply support, movement and transport; infrastructure support; garrison and other shared services 
support; housing, relocations and family support; health support; research and development; communications and information technology support; and administrative services. Agencies that could provide support include: (1) other Defence outputs (e.g., Navy, Army, Air Force, Intelligence); (2) Defence output enablers (e.g., Defence Support and Reform Group (DSRG), Chief Information Officer Group (CIOG), etc.); (3) owner support agencies; (4) civil/private industry/contractors; (5) other Government agencies (e.g., AusAID and Emergency Management Australia); and (6) international support base agencies.

h. Command and management, which includes the responsibilities, defined command and control mechanisms, doctrine, security, processes and procedures to enhance the military effectiveness of Defence. Command and management underpins Defence's operating and management environments through enhanced command and decision-making processes, procedures and management reporting avenues. Command and management processes at all levels are required to plan, apply, measure, monitor and evaluate the functions an agency performs, with due cognisance of risk assessment and subsequent risk management.

Source: Australian Defence Capability Development Handbook (DoD, 2012: 2).

Annex II

NATO categories of military expenditure

NATO reports main military expenditure under the following four categories, which in turn draw on more disaggregated concepts (items) listed below:

Equipment: items $2.1+3.1$ (below),

Personnel: items $1.1+1.2+1.3$,

Infrastructure: items $2.2+2.3$,

Other: items $1.4+3.2+4$.

US dollars are used as the common currency denominator. The exchange rate applied to each NATO ally is the average annual rate published by the International Monetary Fund. The values for defence expenditure are expressed in current prices; constant prices; current prices and exchange rates; as well as constant prices and exchange rates.

1 Operating costs

1.1 Military personnel

1.1.1 pay and allowances

1.1.2 employer's contributions to retirement funds

1.1.3 other

1.2 Civilian personnel

1.2.1 pay and allowances

1.2.2 employer's contributions to retirement funds

1.3 Pensions

1.3.1 military retirees

1.3.2 civilian retirees

1.4 Operations and maintenance

1.4.1 ammunition and explosives (excluding nuclear)

1.4.2 petroleum products

1.4.3 spare parts

1.4.4 other equipment and supplies

1.4.5 rents

1.4.6 other operations and maintenance

2 Procurement and construction

2.1 Major equipment

2.1.1 missile systems

2.1.2 missiles (conventional weapons) 
2.1.3 nuclear weapons

2.1.4 aircraft

2.1.5 artillery

2.1.6 combat vehicles

2.1.7 engineering equipment

2.1.8 weapons and small arms

2.1.9 transport vehicles

2.1.10 ships and harbour craft

2.1.11 electronic and communications equipment

2.2 National military construction

2.3 NATO common infrastructure

2.3.1 expenditure as host country

2.3.2 payments to other countries

2.3.3 receipts from other countries

2.3.4 land and utilities

3 Research and development

3.1 devoted to major equipment

3.2 other

4 Other expenditure

5 Total

6 Statistical discrepancy

7 Adjusted total

Source: NATO (2017: 15)

\section{Annex III}

Australian Defence Organisation outcome and output structure

OUTCOME ONE - Command of Operations in Defence of Australia and its Interests OUTPUTS:

1.1 Command of Operations

1.2 Defence Force Military Operations and Exercises

1.3 Contribution to National Support Tasks

OUTCOME TWO - Navy Capability for the Defence of Australia and its Interests

OUTPUTS:

2.1 Capability for Major Surface Combatant Operations

2.2 Capability for Naval Aviation Operations

2.3 Capability for Patrol Boat Operations

2.4 Capability for Submarine Operations

2.5 Capability for Afloat Support

2.6 Capability for Mine Warfare

2.7 Capability for Amphibious Lift

2.8 Capability for Hydrographic, Meteorological and Oceanographic Operations

OUTCOME THREE - Army Capability for the Defence of Australia and its Interests OUTPUTS:

3.1 Capability for Special Forces Operations 
3.2 Capability for Mechanised Operations

3.3 Capability for Light Infantry Operations

3.4 Capability for Army Aviation Operations

3.5 Capability for Ground-Based Air Defence

3.6 Capability for Combat Support Operations

3.7 Capability for Regional Surveillance

3.8 Capability for Operational Logistic Support to Land Forces

3.9 Capability for Motorised Infantry Operations

3.10 Capability for Protective Operations

OUTCOME FOUR - Air Force Capability for the Defence of Australia and its Interests

OUTPUTS:

4.1 Capability for Air Combat Operations

4.2 Capability for Combat Support of Air Operations

4.3 Capability for Surveillance and Response Operations (1)

4.4 Capability for Air Lift

OUTCOME FIVE - Strategic Policy for the Defence of Australia and its Interests

OUTPUTS:

5.1 Strategic and International Policy, Activities and Engagement

5.2 Military Strategy and Capability Analysis(2)

OUTCOME SIX - Intelligence for the Defence of Australia and its Interests

OUTPUT:

6.1 Intelligence

OUTCOME SEVEN - Superannuation and Housing Support Services for Current and Retired Defence Personnel OUTPUT:

7.1 Superannuation and Housing Support Services for Current and Retired Defence Personnel

Source: PBS (2004).

\section{Copyrights}

Copyright for this article is retained by the author(s), with first publication rights granted to the journal.

This is an open-access article distributed under the terms and conditions of the Creative Commons Attribution license which permits unrestricted use, distribution, and reproduction in any medium, provided the original work is properly cited. 